\title{
Causes of False-Positive Radioactive Iodine Uptake in Patients with Differentiated Thyroid Cancer
}

\author{
Karin $\mathrm{Wu}^{1} \cdot$ Uzoezi Ozomaro $^{2} \cdot$ Robert Flavell $^{2} \cdot$ Miguel Pampaloni $^{2}$. \\ Chienying $\operatorname{Liu}^{1}$ (D)
}

Accepted: 4 May 2021 / Published online: 19 May 2021

(C) The Author(s) 2021

\begin{abstract}
Purpose Radioactive iodine (RAI) whole-body scan is a sensitive imaging modality routinely used in patients with differentiated thyroid cancer to detect persistent and recurrent disease. However, there can be false-positive RAI uptake that can lead to misdiagnosis and misclassification of a patient's cancer stage. Recognizing the causes of false positivity can avoid unnecessary testing and treatment as well as emotional stress. In this review, we discuss causes and summarize various mechanisms for false-positive uptake.

Recent Findings We report a patient with differentiated thyroid cancer who was found to have Mycobacterium avium complex infection as the cause of false-positive RAI uptake in the lungs. Using this case example, we discuss and summarize findings from the literature on etiologies of false-positive RAI uptake. We also supplement additional original images illustrating other examples of false RAI uptake.

Summary False-positive RAI uptake may arise from different causes and RAI scans need to be interpreted in the context of the patient's history and corresponding crosssectional imaging findings on workup. Understanding the
\end{abstract}

This article is part of the Topical collection on Nuclear Medicine \& PET/CT Imaging.

Chienying Liu

chienying.liu@ucsf.edu

1 Division of Diabetes, Endocrinology and Metabolism, Department of Medicine, University of California, San Francisco, CA, USA

2 Department of Radiology and Biomedical Imaging, University of California, San Francisco, CA, USA potential pitfalls of the RAI scan and the mechanisms underlying false uptake are vital in the care of patients with differentiated thyroid cancer.

Keywords Radioiodine - I-131 · Whole-body scintigraphy - False-positive uptake - Differentiated thyroid cancer

\section{Introduction}

Differentiated thyroid cancer (DTC), which includes papillary and follicular histologic types, constitutes greater than $90 \%$ of all thyroid cancer cases [1]. Although there is an uptrend in the diagnosis of DTC over the past several decades, with an average annual increase in the incidence of $3.6 \%$ in the USA [2], the mortality rate has remained quite low. The good prognosis can be attributed to the less aggressive behavior of most DTC and the effective use of radioactive iodine (RAI) after total thyroidectomy in patients who are at risk for persistent or recurrent disease [3].

The use of RAI has been an integral component of care for patients with DTC after thyroidectomy since the 1940s [4]. RAI whole-body scan (WBS) informs clinicians of disease staging and documents RAI avidity of any structural disease, and it is a critical tool in the treatment and surveillance of DTC $[5,6]$. The principle of RAI use in diagnosing and treating DTC is that some thyroid cancer cells retain expression of the sodium-iodide symporter (NIS), which is a plasma membrane glycoprotein that facilitates active iodide transport $[7 \cdot \bullet]$. However, NIS expression is not specific to thyroid cells. The false-positive findings on RAI-WBS can be due to ectopic thyroid tissue, physiologic NIS expression in other tissues, RAI retention in body cavities or ducts, direct RAI bonding to 
metallic foreign bodies, contamination, inflammation and infection, and non-thyroid neoplasms. Therefore, the finding of unexpected iodine uptake should be interpreted in the context of the patient's medical history, thyroglobulin levels, and histopathologic features of the tumor, corroborated with cross-sectional imaging studies. Tissue sampling may be needed in some situations.

This review will focus on the various causes of falsepositive WBS results and discuss a case example illustrating the potential pitfalls of making clinical judgments solely based on the WBS.

\section{Case}

A 51-year-old woman with a history of stage 1B breast cancer treated with mastectomy and adjuvant radiotherapy, was found on breast cancer staging computed tomography (CT) scan to have several hypodense thyroid nodules with dystrophic calcifications. Subsequent workup followed by total thyroidectomy with paratracheal lymph node dissection showed a $1.8-\mathrm{cm}$ follicular variant papillary thyroid carcinoma (PTC) with lymphovascular invasion and positive margins without extrathyroidal extension. There were 4/4 positive lymph nodes with perinodal soft tissue extension, amounting to a pathological stage of pT1bN1aM0 and clinical stage I [8]. Three months later, the patient was treated with $73.6 \mathrm{mCi}(2723 \mathrm{MBq})$ of I-131, and the post-treatment WBS showed accumulation in the thyroid remnant and thoracic outlet lymph nodes without lung or bone uptake (Fig. 1). Stimulated thyroglobulin was $92.8 \mathrm{ng} / \mathrm{mL}$ [reference: no evidence of disease defined as $<1 \mathrm{ng} / \mathrm{mL}$ ] with thyrotropin (TSH) level of $205 \mathrm{mIU} / \mathrm{L}$ [reference: $0.4-4.5 \mathrm{mIU} / \mathrm{L}$ ]. In the next year, the patient had two additional paratracheal lymph node dissections.

Despite repeated surgeries, the patient continued to have a biochemically incomplete response. Her thyroglobulin levels remained stably elevated around $4-5 \mathrm{ng} / \mathrm{mL}$ on TSH suppression and around $20 \mathrm{ng} / \mathrm{mL}$ on recombinant human thyrotropin (rhTSH) stimulation. Six months after the most recent lymph node dissection and about two years after the initial diagnosis, she underwent a second RAI treatment with $100 \mathrm{mCi}(3700 \mathrm{MBq}$ ) of I-131. Her stimulated thyroglobulin level was $21.6 \mathrm{ng} / \mathrm{mL}$. This time, the posttreatment RAI-WBS exhibited intense uptake within the lung fields and the thyroid bed (Fig. 2). The new finding of pulmonary uptake prompted a $[18 \mathrm{~F}]$ fluorodeoxyglucose positron emission tomography/computed tomography (FDG PET/CT) scan, which showed findings consistent with right cervical nodal metastases and suggestive of lung metastases (Fig. 3a-d). Four months later, the suppressed thyroglobulin level remained unchanged at $4 \mathrm{ng} / \mathrm{mL}$.
Since it was presumed that the patient had local and distant metastatic disease, she was referred to our institution for further management. The distribution of the lung nodules on FDG PET/CT was found to be atypical for metastatic disease; Chest CT was obtained to further characterize the lung nodules, and it revealed probable chronic airway infection given mucus impaction, bronchiectasis, and clustered subcentimeter nodular opacities throughout the lingula, right middle, and left lower lobes, suggestive of atypical mycobacterial infection (Fig. $3 e$ and $\mathrm{f}$ ). The area of these abnormalities corresponded to the uptake on the WBS. The patient underwent bronchoscopy with bronchoalveolar lavage and was diagnosed with Mycobacterium avian complex (MAC) infection. Thus, the RAI uptake in the lungs was favored to be a spurious finding due to underlying pulmonary infection rather than metastatic thyroid cancer. The source of her elevated thyroglobulin was attributed to cervical and mediastinal nodal disease that was found on subsequent neck ultrasound and magnetic resonance imaging.

\section{Discussion}

Despite the high diagnostic sensitivity and specificity of RAI-WBS for persistent or recurrent DTC, false-positive results can occur and be due to a variety of causes (Table 1). The major diagnostic dilemma is when falsepositive uptake occurs in areas where DTC frequently metastasizes to, such as the bones and lungs, as shown in our case. We review additional causes of RAI-WBS false positivity, which are summarized below.

\section{Physiologic Causes}

\section{Extraglandular Thyroid Tissue}

Embryologically, thyroid tissues originate at the base of the tongue and migrate caudally along the midline via the thyroglossal duct. Failure of embryologic decent leads to ectopic thyroid tissues; the most common locations are at the base of the tongue and along the thyroglossal duct [9]. Other rarer sites can be mediastinal, intrathoracic, and in distant subdiaphragmatic locations [10]. Ectopic thyroid tissues are functional, and therefore, can take up RAI similarly to a normal thyroid gland [11]. The prevalence of ectopic thyroid is low, about 1 in 100,000 to 300,000 people, which is likely an underestimation since the clinical prevalence of those with thyroid disease is about 1 in 4000 to 8000 people [10].

Struma ovarii is a rare variant of an ovarian teratoma composed of more than $50 \%$ of mature thyroid tissues. It comprises roughly $1 \%$ of all ovarian tumors and $2.7 \%$ of all 

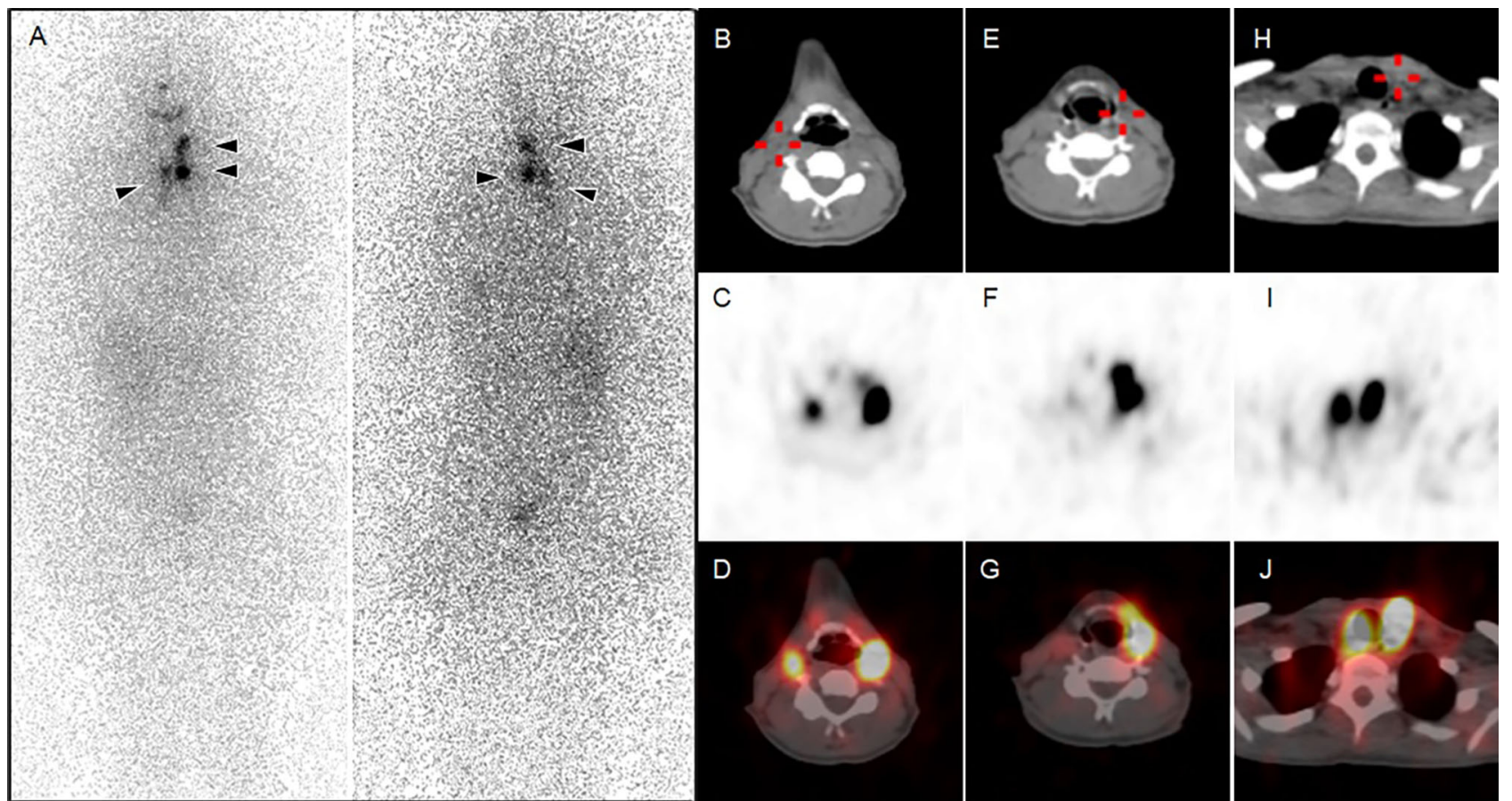

C

F

$$
\text { I }
$$
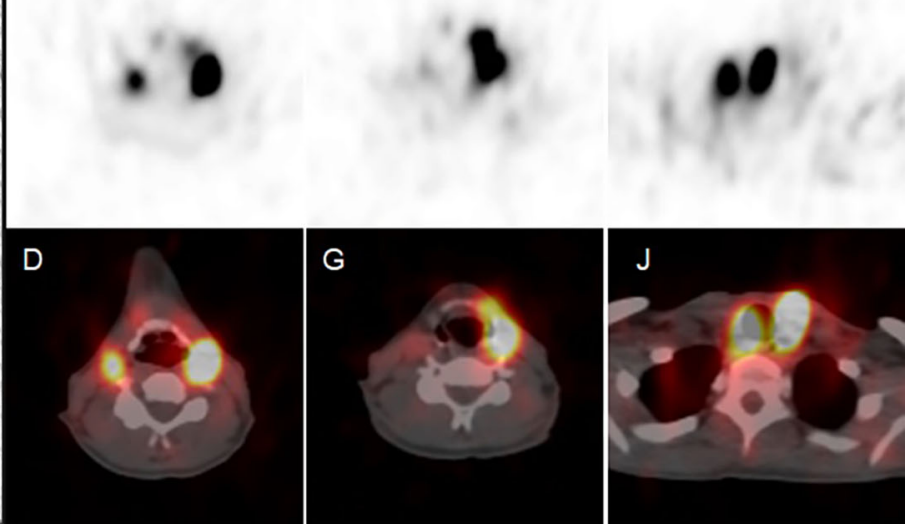

Fig. 1 Imaging after initial I-131 treatment. a RAI-WBS with accumulation in the thyroid remnant and neck lymph nodes. b, e CT, c, $\mathbf{f}$ single-photon emission computed tomography (SPECT), and d, g transaxial fused SPECT/CT identified bilateral upper and middle cervical lymph nodes with uptake of the radiopharmaceutical. h CT, i SPECT and $\mathbf{j}$ transaxial fused SPECT/CT identified left thyroid remnant and right upper paratracheal nodal uptake of the radiopharmaceutical

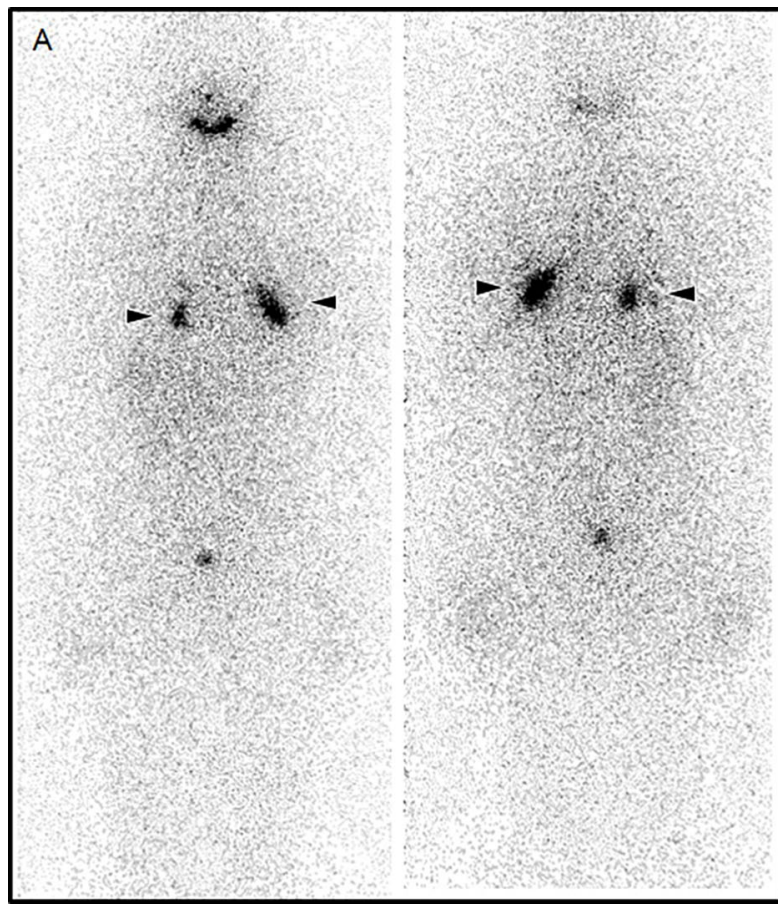

Fig. 2 Imaging after repeat I-131 treatment. a RAI-WBS with accumulation in the lungs and the thyroid bed. b CT, c SPECT, and d transaxial fused SPECT/CT identified thyroid bed
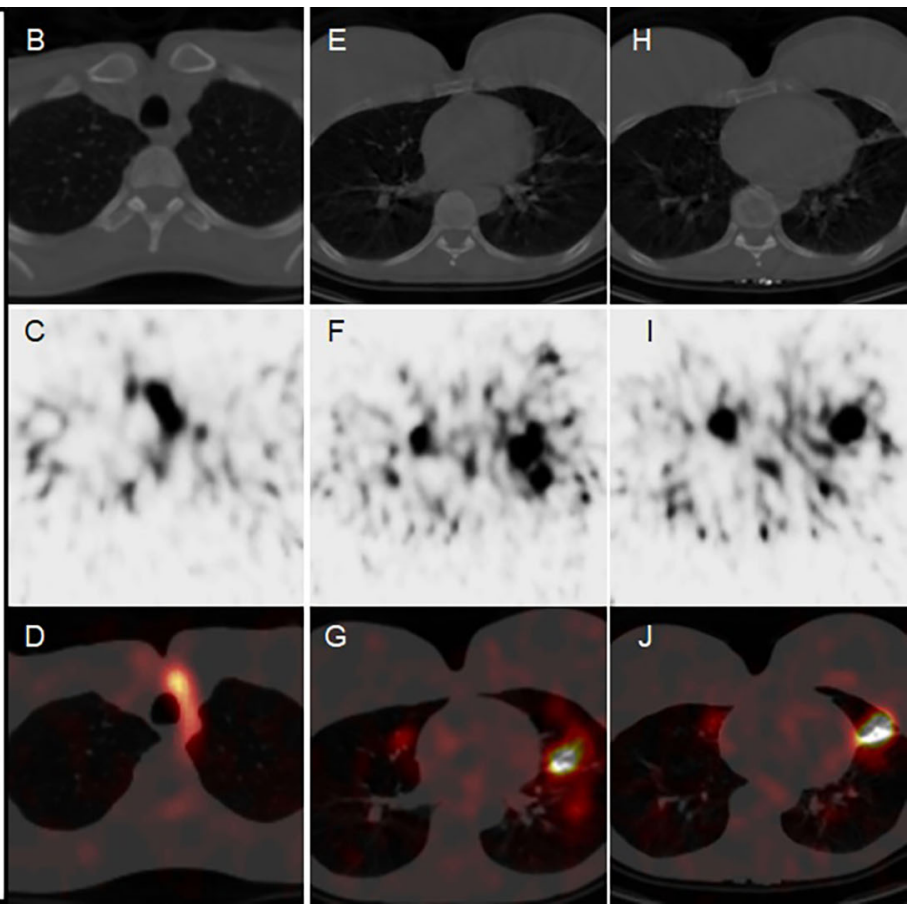

radiopharmaceutical uptake. $\mathbf{e}, \mathbf{h} \mathrm{CT}, \mathbf{f}, \mathbf{i}$ SPECT and $\mathbf{g}, \mathbf{j}$ transaxial fused SPECT/CT identified bilateral pulmonary radiopharmaceutical uptake 


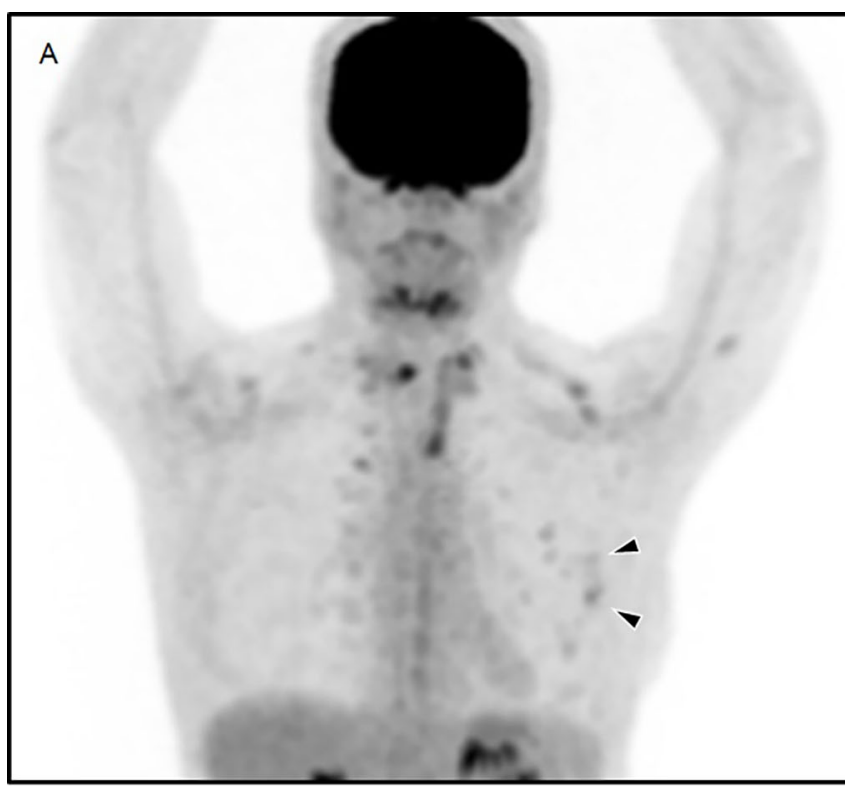

Fig. 3 Imaging to characterize extent of structural disease. PET/CT images including a maximum intensity projection (MIP), b CT, c PET, d transaxial fused PET/CT. CT scan performed following

ovarian teratomas [12]. False-positive RAI uptake has been described in struma ovarii [13-15] and in ovarian teratomas with or without thyroid parenchyma [16, 17].

\section{Uptake in Non-thyroidal Tissue}

Expression of NIS in other tissues constitutes an important mechanism of RAI uptake outside of the thyroid. Clinically relevant sites include the salivary glands, lacrimal glands, gastrointestinal tract, choroid plexus, and mammary glands [7••]. The physiologic uptake of RAI in salivary glands is a reason for the commonly observed salivary gland-related side effects such as dry mouth, sialadenitis, and altered taste in up to $40 \%$ of patients receiving RAI doses of $75 \mathrm{mCi}(2775 \mathrm{MBq})$ or greater [18]. A more recent systemic review found that salivary gland dysfunction can be found in 16-54\% of patients receiving RAI [19]. Mammary glands have been shown to be a major organ expressing NIS with a marked upregulation during lactation by oxytocin and prolactin $[20,21]$. Uptake has been described not only in lactating breasts [22] but also in non-lactating breasts [23]. In addition, there was a reported case of bilateral breast RAI concentration in the setting of a pituitary macroprolactinoma [24], which is caused by hyperprolactinemia leading to upregulation of NIS expression. It is essential to correlate the potential uptake in breast tissues clinically and radiographically with single-photon emission computed tomography (SPECT-CT) as the uptake can be misinterpreted as pulmonary metastases given its location.

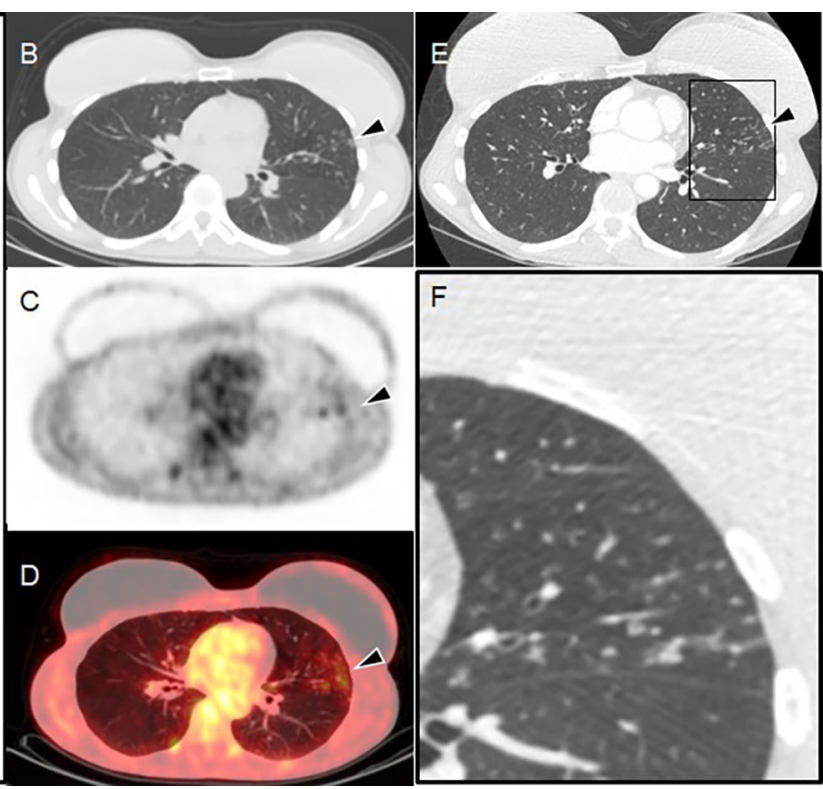

patient referral to our institution and two months after the second I-131 treatment showed pulmonary nodules and linear thickening $\mathbf{e}$ at $1 \times$ and $\mathbf{f}$ at $2.71 \times$ inset magnification

A frequent finding on RAI-WBS is diffuse uptake of RAI in the liver, reported in $40-94 \%$ of patients [25-28]. The exact mechanism is unknown. One proposed mechanism is hepatic metabolism of organified RAI released from the thyroid tissue. This mechanism and the clinical significance are debated, with some reporting an association with residual thyroid tissue [25, 26], while others suggest no correlation with serum thyroglobulin levels or presence of thyroid tissue or disease [27, 29]. Intrahepatic bile duct NIS expression is another postulated mechanism since some report correlation between hepatic uptake and dose of RAI [25-27]. Hepatic steatosis and elevated hepatic enzymes have also been shown to be associated with RAI uptake, both may cause delayed de-iodination and iodine excretion leading to higher liver retention [27, 30••].

RAI uptake by the thymus has been described most often in young patients $(<50$ years of age) [31-33]. The mechanism has been attributed to the expression of NIS and thyroid-related proteins in human thymic tissues [34]. However, a study found no difference in NIS and TSH receptor expression with age [35]. An alternate explanation is that older patients have lower thymic tissue volume since the thymus involutes with age, so thymic RAI uptake is less frequently seen in this population.

\section{Radioiodinated Bodily Fluid Retention}

An oral dose of RAI is quickly and almost entirely absorbed via the gastrointestinal tract. In fact, more than $90 \%$ of the dose is then excreted through the kidney over 
Table 1 Summary of the causes of false-positive RAI uptake

\begin{tabular}{|c|c|c|c|}
\hline \multicolumn{2}{|l|}{ Physiologic } & \multicolumn{2}{|l|}{ Pathologic } \\
\hline Mechanism & Causes & Mechanism & Causes \\
\hline $\begin{array}{l}\text { Sodium-iodide } \\
\text { symporter } \\
\text { (NIS) } \\
\text { expression }\end{array}$ & $\begin{array}{l}\text { Thyroid tissue } \\
\text { Ectopic thyroid along embryonic migration tract } \\
\text { (base of tongue and along thyroglossal duct) } \\
\text { Struma ovarii } \\
\text { Non-thyroid tissue } \\
\text { Salivary glands, lacrimal glands, gastrointestinal } \\
\text { tract, choroid plexus, mammary glands, thymus }\end{array}$ & $\begin{array}{l}\text { Sodium-iodide } \\
\text { symporter (NIS) } \\
\text { expression }\end{array}$ & $\begin{array}{l}\text { Benign tumors with NIS expression (non- } \\
\text { thyroid) } \\
\text { Salivary gland tumors, breast fibroadenomas, } \\
\text { ovarian tumors (cystadenomas) } \\
\text { Malignant tumors with NIS expression (non- } \\
\text { thyroid) } \\
\text { Breast, prostate, ovary, lung, colon, } \\
\text { endometrium }\end{array}$ \\
\hline $\begin{array}{l}\text { Retention of } \\
\text { radioiodinated } \\
\text { bodily fluids }\end{array}$ & $\begin{array}{l}\text { Normal anatomy } \\
\text { Bladder (urine), colon (feces), esophagus (saliva) } \\
\text { Anatomical anomaly } \\
\text { Cystic structures (nasolacrimal sac, } \\
\text { pleuropericardial, bronchogenic, thymic, breast, } \\
\text { hepatic, renal, retroperitoneal, ovarian, } \\
\text { Nabothian, sebaceous, epithelial) } \\
\text { Diverticula (esophageal, epiphrenic, Meckel's, } \\
\text { appendix, pelvicalyceal) } \\
\text { Vascular aneurysms/ectasia } \\
\text { Ductal/tubal dilation and obstruction } \\
\text { (nasolacrimal, parotid gland, salivary gland, } \\
\text { achalasia, hiatal hernia, gastric volvulus, biliary } \\
\text { tract) } \\
\text { Ectopic kidney }\end{array}$ & Hyperemia/vascularity & $\begin{array}{l}\text { Inflammation } \\
\text { Bronchiectasis, asthma exacerbation, } \\
\text { rheumatoid arthritis, folliculitis, sialadenitis, } \\
\text { sinusitis, cholecystitis } \\
\text { Infections } \\
\text { Respiratory (fungal infection such as } \\
\text { aspergilloma, bacterial infection such as } \\
\text { tuberculosis and Mycobacterium avium } \\
\text { complex) } \\
\text { Liver abscess } \\
\text { Trauma } \\
\text { Benign tumors with high vascularity (non- } \\
\text { thyroid) } \\
\text { Meningiomas, angiomas/hemangiomas } \\
\text { Malignant tumors, primary or metastasis } \\
\text { (non-thyroid) }\end{array}$ \\
\hline $\begin{array}{l}\text { Direct RAI } \\
\text { bonding to } \\
\text { metallic } \\
\text { foreign bodies }\end{array}$ & $\begin{array}{l}\text { Copper intrauterine devices } \\
\text { Surgical clips, metallic sutures }\end{array}$ & & \\
\hline $\begin{array}{l}\text { Contamination } \\
\text { by } \\
\text { radioiodinated } \\
\text { bodily fluids }\end{array}$ & $\begin{array}{l}\text { Skin, hair, clothes, prosthesis, tracheostomy or } \\
\text { gastrostomy site }\end{array}$ & & \\
\hline
\end{tabular}

5 days, with the majority disposed in the first $24 \mathrm{~h}$ [36]. The remaining RAI is excreted via sweat, gut, and other bodily secretions. Any retention of body fluids with or without anatomical abnormalities can be seen on WBS. Commonly, radioiodinated urinary retention in the bladder, salivary retention in the esophagus, and large intestinal retention of feces are noted, especially if the WBS is obtained soon after RAI administration.

Many cases of anatomical variation have been reported to lead to false-positive RAI retention. Examples include cystic and pouch-like structures such as nasolacrimal sac cyst [37], esophageal diverticulum [38-40], epiphrenic diverticulum [41], pleuropericardial cyst [42], bronchogenic cyst [43, 44], thymic cyst (Fig. 4) [45, 46], breast cyst [47], Meckel's diverticulum [48], appendix [49], pelvocalyceal diverticulum [50,51], hepatic cyst [52-54], renal cyst [55-58], retroperitoneal cyst [59•], ovarian cyst [60, 61], nabothian cyst [62], sebaceous cyst [63, 64], and epithelial cyst [65]. Arterial dilation leading to stasis of blood flow has also been shown to have false-positive RAI retention $[66,67]$. The mechanism is the passive diffusion of iodine into cysts and diverticula that becomes trapped due to the slow drainage. Ovarian cysts are commonly found in women of reproductive age, with the vast majority being physiologically functional [68]. Functional ovarian cysts have been described to retain RAI uptake [61]. Thus, a potential clinical implication is to time the RAI administration with the menstrual cycle in premenopausal women to minimize this potential uptake in these cysts.

Ductal and tubular pathology or dilation can cause retention of RAI as well. Cases in the head and neck include nasolacrimal duct obstruction [69], parotid gland 


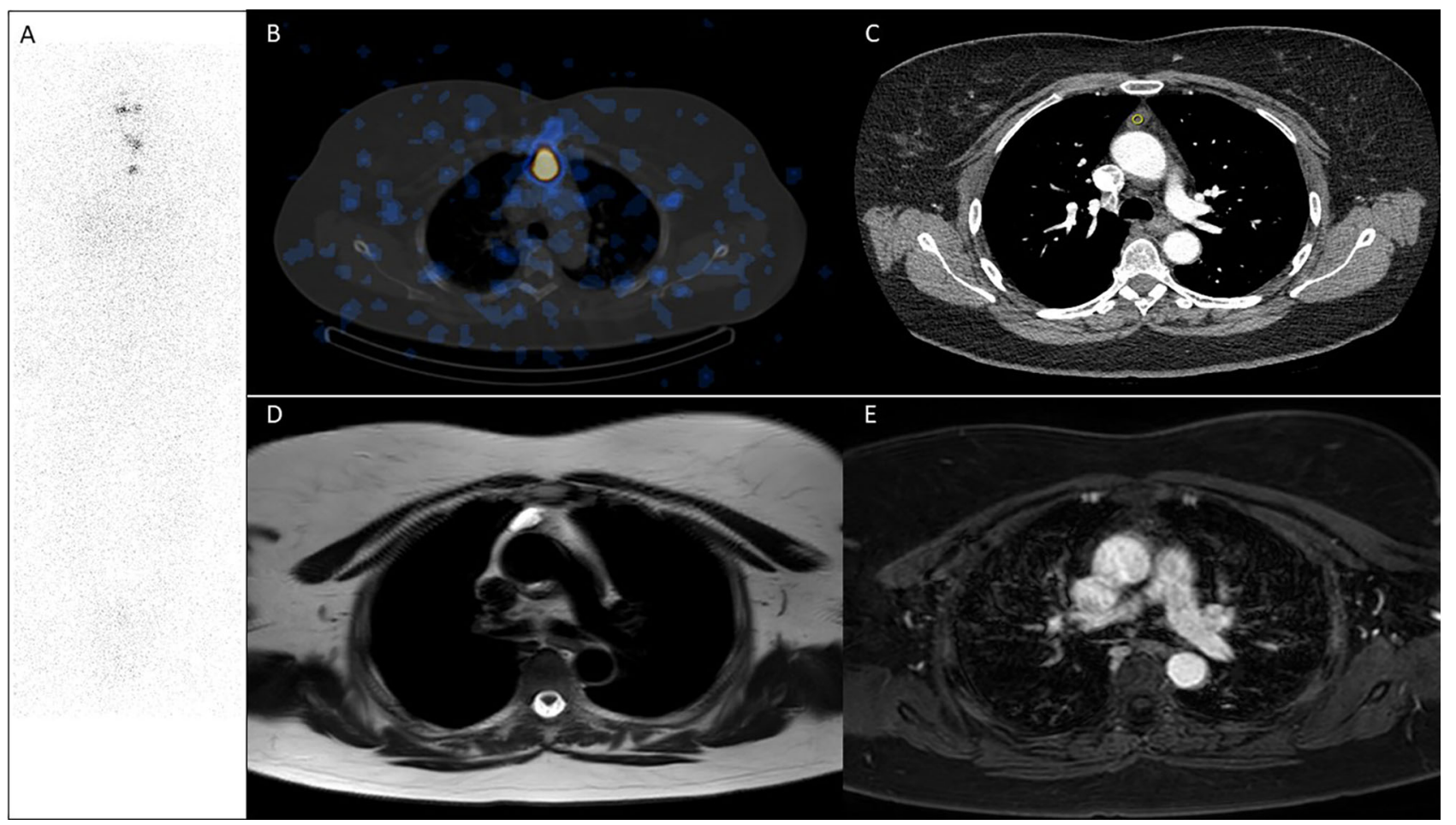

Fig. 4 I-131 retention in thymic cyst. a RAI-WBS, b SPECT/CT, $\mathbf{c}$ CT with contract, $\mathbf{d}$ MRI T2-weighted, e MRI post-gadolinium identified I-131 retention in thymic cyst

duct ectasia [70], and xerostomia [71]. In the gastrointestinal tract, cases of false positivity have been demonstrated in achalasia [72], esophageal scarring [73], hiatal hernia [74, 75], gastric volvulus [76], and biliary tract obstruction [77]. Other reported anomalies with RAI uptake are seen in ectopic kidney [78] and hematocolpos [79]. The patient's medical history and cross-sectional images can aid in identifying these structural anomalies.

\section{Direct RAI Bonding to Metallic Foreign Bodies}

Various metallic foreign bodies have been shown to have apparent increased RAI uptake on RAI-WBS. One of the most commonly seen materials with this behavior is dental amalgam (Fig. 5a) [80, 81]. The proposed mechanism of tracer retention demonstrated by in-vitro binding assays is the interaction and chemical binding of negatively charged iodide ions to the positively charged metal ions [80, 81]. Through a similar mechanism, copper intrauterine devices (Fig. 5b), metallic surgical clips, and metallic sutures also retain RAI tracer [82-85॰]. Moreover, these foreign bodies induce a local inflammatory response that subsequently may lead to RAI uptake in surrounding tissues (see Section on Inflammation and infection).

\section{Contamination by Radioiodinated Bodily Fluid}

Contamination artifacts are caused by radioiodinated bodily fluids on the skin, hair, and clothes. Perspiration can result in skin and hair contamination in the axilla [86] and scalp [87]. Contamination has also been described in artificial eyeballs by tear contamination [88•, 89•] and within tracheostomy sites [90]. Uptake from contamination tends to be superficial and/or in odd locations, and this can be easily corrected by washing the suspected area or by removing contaminated clothing.

\section{Pathologic Causes}

\section{Inflammation and Infection}

Inflammation and infection can cause spurious RAI uptake. The proposed mechanisms are inflammation-mediated hyperemia, increased vessel permeability, and possibly, increased retention of organified I-131 by leukocytes during bactericidal activity [91]. Diseases of the lungs are particularly important clinical entities because of their mimicry of pulmonary metastases. Conditions of the lungs such as bronchiectasis [92-94], acute respiratory infection [95], asthma exacerbation [96•], and fungal infections like aspergilloma [97] and tuberculosis [98, 99] have been known to cause spurious RAI uptake. Case reports of 

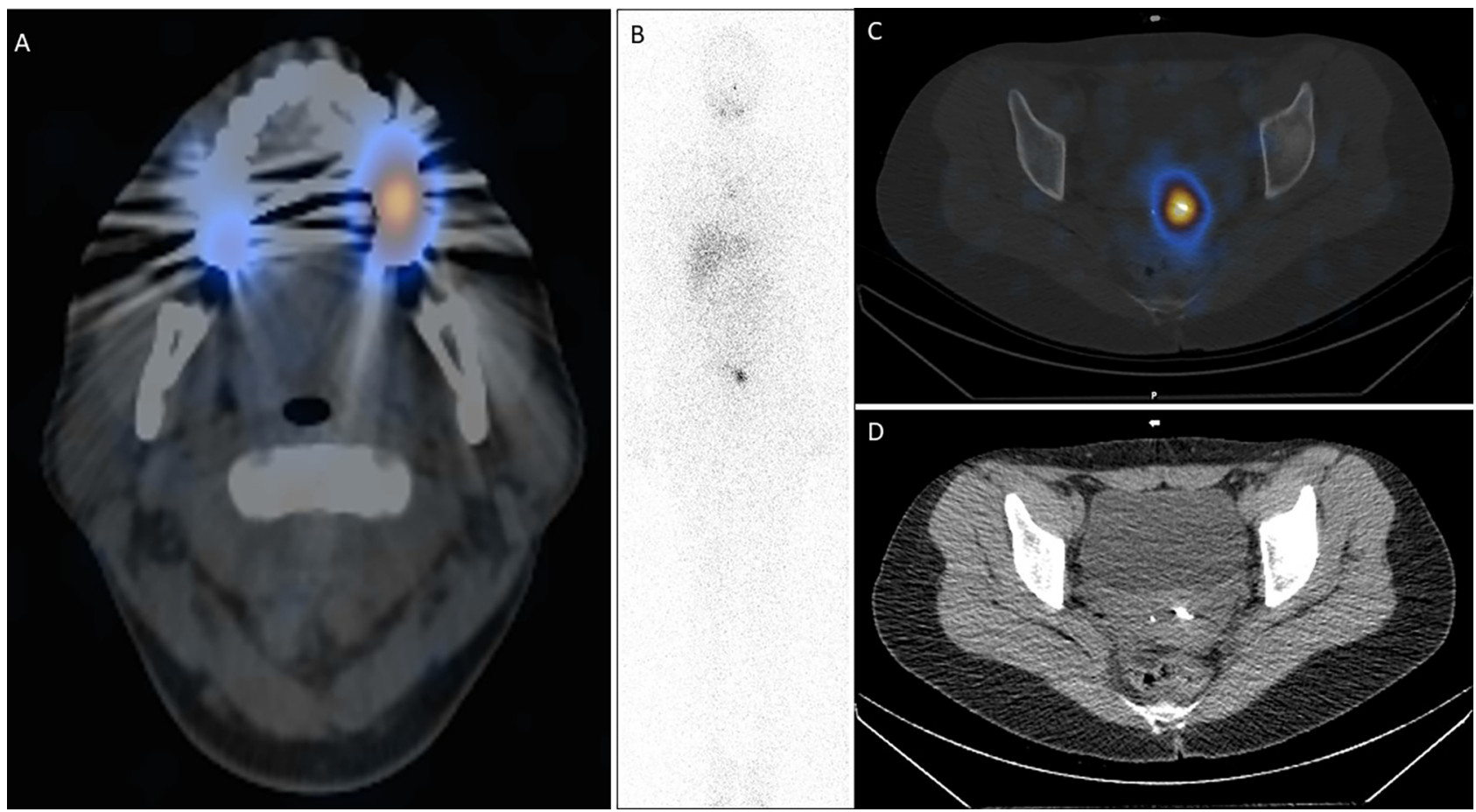

Fig. 5 I-131 retention by direct chemical binding to metallic foreign bodies. a SPECT/CT with RAI retention in dental amalgam. b RAI-WBC, c SPECT/CT, and $\mathbf{d}$ CT showing uptake by copper intrauterine device

inflammatory and infectious conditions causing RAI uptake in other body sites include rheumatoid arthritis [100], folliculitis [101•, 102], sialadenitis [103], sinusitis [104], cholecystitis [64], and liver abscess [105].

Our case describes a case of Mycobacterium avium complex infection causing chronic inflammation and bronchiectasis in the lungs. The distribution of pulmonary nodules on cross-sectional imaging with its corresponding RAI uptake on RAI-WBS was unusual for metastatic thyroid cancer, which typically spreads with hematogenous dissemination producing a miliary or randomly distributed pattern of nodules throughout all lobes, often with a basilar predominance [106]. The discordant findings prompted further evaluation and eventual diagnosis of the underlying cause. Our case highlights the importance of a multi-disciplinary team approach to explain questionable findings.

\section{Trauma}

Similarly, trauma also leads to increased perfusion and vasodilation and can be a cause of false positivity. In fact, there has been a reported case of chest wall uptake after needle biopsy [107] and uptake in post-traumatic superficial scabs [108].

\section{Benign and Malignant Tumors}

Benign tumors may have unexpected uptake of RAI. The mechanism can be due to functional physiologic NIS expression in the parenchymal tissues, such as in salivary gland tumors [109-112], breast fibroadenomas [113], and ovarian tumors [114-117]. Tumors with high vascularity, such as meningiomas [118, 119] and angiomas/hemangiomas [120-124] can cause RAI pooling and uptake on RAI-WBS.

Pathologic RAI accumulation in non-thyroid malignancies and metastases occurs in various body sites. The underlying mechanisms are similar to benign tumors, including NIS expression, high vascularity, and in addition, local tumoral inflammatory response in these malignancies. NIS expression is shown in carcinomas of the prostate, ovary, lung, colon, endometrium, and breast [125, 126]. Since NIS expression has been found by immunohistochemistry in about $80 \%$ of human breast cancers, there is a growing interest in employing RAI in the treatment of breast cancer [127].

\section{Conclusion}

RAI-WBS is an essential diagnostic tool for detecting normal thyroid tissue and metastatic differentiated thyroid cancer based on iodine avidity of the follicular thyroid cells 
mediated by the sodium-iodide symporter. It can detect persistent or recurrent disease after thyroidectomy. However, a variety of other disease and physiologic processes can cause false-positive results, and without careful evaluation, misinterpretation can lead to a cascade of diagnostic procedures and unnecessary treatment, which are not only expensive, but can be emotionally taxing on the patient.

Our case is a salient demonstration of how false-positive RAI uptake can be encountered in clinical practice. It highlights the potential pitfalls of the RAI-WBS and the importance of interpreting the results in the context of clinical presentation and corroborating cross-section imaging studies, especially when the uptake patterns are unusual. It is important for clinicians taking care of patients with DTC to recognize the potential causes and mechanisms for false-positive RAI uptake.

Funding This study was funded by National Institute of Diabetes and Digestive and Kidney Diseases (Grant No. 5T32DK007418).

\section{Declarations}

Conflict of interest The authors have nothing to disclose.

Open Access This article is licensed under a Creative Commons Attribution 4.0 International License, which permits use, sharing, adaptation, distribution and reproduction in any medium or format, as long as you give appropriate credit to the original author(s) and the source, provide a link to the Creative Commons licence, and indicate if changes were made. The images or other third party material in this article are included in the article's Creative Commons licence, unless indicated otherwise in a credit line to the material. If material is not included in the article's Creative Commons licence and your intended use is not permitted by statutory regulation or exceeds the permitted use, you will need to obtain permission directly from the copyright holder. To view a copy of this licence, visit http://creativecommons. org/licenses/by/4.0/.

\section{References}

Recently published papers of particular interest have been highlighted as:

- Of importance

•- Of major importance

1. Sherman SI. Thyroid carcinoma. Lancet. 2003;361(9356):501-11.

2. Lim H, Devesa SS, Sosa JA, Check D, Kitahara CM. Trends in thyroid cancer incidence and mortality in the United States, 1974-2013. JAMA. 2017;317(13):1338-48.

3. Orosco RK, Hussain T, Noel JE, Chang DC, Dosiou C, Mittra E, et al. Radioactive iodine in differentiated thyroid cancer: a national database perspective. Endocr Relat Cancer. 2019;26(10):795-802.
4. Seidlin SM, Marinelli LD, Oshry E. Radioactive iodine therapy; effect on functioning metastases of adenocarcinoma of the thyroid. J Am Med Assoc. 1946;132(14):838-47.

5. Haugen BR. 2015 American Thyroid Association Management Guidelines for adult patients with thyroid nodules and differentiated thyroid cancer: what is new and what has changed? Cancer. 2017;123(3):372-81.

6. Haugen BR, Alexander EK, Bible KC, Doherty GM, Mandel SJ, Nikiforov YE, et al. 2015 American Thyroid Association Management Guidelines for Adult Patients with Thyroid Nodules and Differentiated Thyroid Cancer: the American Thyroid Association Guidelines task force on thyroid nodules and differentiated thyroid cancer. Thyroid. 2016;26(1):1-133.

7. • Ravera S, Reyna-Neyra A, Ferrandino G, Amzel LM, Carrasco $\mathrm{N}$. The sodium/iodide symporter (NIS): molecular physiology and preclinical and clinical applications. Annu Rev Physiol. 2017;79:261-89 A recent review article on iodide homeostasis and properties of sodium-iodide symporter, which are important to understand some of the mechanisms for false-positive RAI uptake.

8. Perrier ND, Brierley JD, Tuttle RM. Differentiated and anaplastic thyroid carcinoma: Major changes in the American Joint Committee on Cancer eighth edition cancer staging manual. CA Cancer J Clin. 2018;68(1):55-6

9. Alanazi SM, Limaiem F. Ectopic thyroid. StatPearls. Treasure Island (FL) 2020

10. Noussios G, Anagnostis P, Goulis DG, Lappas D, Natsis K. Ectopic thyroid tissue: anatomical, clinical, and surgical implications of a rare entity. Eur J Endocrinol. 2011;165(3):375-82.

11. Triggiani V, Giagulli VA, Licchelli B, Resta F, Fiore G, De Pergola G, et al. Ectopic thyroid gland: description of a case and review of the literature. Endocr Metab Immune Disord Drug Targets. 2013;13(3):275-81.

12. Yoo SC, Chang KH, Lyu MO, Chang SJ, Ryu HS, Kim HS. Clinical characteristics of struma ovarii. J Gynecol Oncol. 2008;19(2):135-8.

13. Salvatori M, Rufini V, Daidone MS, Danza FM, Valentini AL, Negro F, et al. Occasional detection of "struma ovarii" in a patient with thyroid carcinoma. Radiol Med. 1991;81(5):744-7.

14. Ghander C, Lussato D, Conte Devolx B, Mundler O, Taieb D. Incidental diagnosis of struma ovarii after thyroidectomy for thyroid cancer: functional imaging studies and follow-up. Gynecol Oncol. 2006;102(2):378-80.

15. Macdonald W, Armstrong J. Benign struma ovarii in a patient with invasive papillary thyroid cancer: detection with I-131 SPECT-CT. Clin Nucl Med. 2007;32(5):380-2.

16. Rudoni S, Toubeau M, Vaillant G, Arnould L, Verges B, Brun JM, et al. Dermoid cyst of the ovary False positive diagnosis in iodine 131 scintigraphy of differentiated thyroid cancers. Presse Med. 1998;27(27):1379-81.

17. van Wijk JP, Broekhuizen-de Gast HS, Smits AJ, Schipper ME, Zelissen PM. Scintigraphic detection of benign ovarian teratoma after total thyroidectomy and radioactive iodine for differentiated thyroid cancer. J Clin Endocrinol Metab. 2012;97(4):1094-5.

18. Grewal RK, Larson SM, Pentlow CE, Pentlow KS, Gonen M, Qualey R, et al. Salivary gland side effects commonly develop several weeks after initial radioactive iodine ablation. J Nucl Med. 2009;50(10):1605-10.

19. Clement SC, Peeters RP, Ronckers CM, Links TP, van den Heuvel-Eibrink MM, van Dijkum NEJ, et al. Intermediate and long-term adverse effects of radioiodine therapy for differentiated thyroid carcinoma-a systematic review. Cancer Treat Rev. 2015;41(10):925-34.

20. Cho JY, Leveille R, Kao R, Rousset B, Parlow AF, Burak WE $\mathrm{Jr}$, et al. Hormonal regulation of radioiodide uptake activity and 
$\mathrm{Na}+$ /I- symporter expression in mammary glands. J Clin Endocrinol Metab. 2000;85(8):2936-43.

21. Tazebay UH, Wapnir IL, Levy O, Dohan O, Zuckier LS, Zhao $\mathrm{QH}$, et al. The mammary gland iodide transporter is expressed during lactation and in breast cancer. Nat Med. 2000;6(8):871-8.

22. Bakheet SM, Hammami MM. Patterns of radioiodine uptake by the lactating breast. Eur J Nucl Med. 1994;21(7):604-8.

23. Hammami MM, Bakheet S. Radioiodine breast uptake in nonbreastfeeding women: clinical and scintigraphic characteristics. J Nucl Med. 1996;37(1):26-31.

24. Hu LH, Wang SJ, Liu RS. Hyperprolactinemia-related (1)(3)(1)I uptake in nonlactating breasts. Clin Nucl Med. 2012;37(3):e57-8.

25. Ziessman HA, Bahar H, Fahey FH, Dubiansky V. Hepatic visualization on iodine-131 whole-body thyroid cancer scans. J Nucl Med. 1987;28(9):1408-11.

26. Chung JK, Lee YJ, Jeong JM, Lee DS, Lee MC, Cho BY, et al. Clinical significance of hepatic visualization on iodine-131 whole-body scan in patients with thyroid carcinoma. J Nucl Med. 1997;38(8):1191-5.

27. Omur O, Akgun A, Ozcan Z, Sen C, Ozkilic H. Clinical implications of diffuse hepatic uptake observed in postablative and post-therapeutic I-131 scans. Clin Nucl Med. 2009;34(1):11-4.

28. Rosenbaum RC, Johnston GS, Valente WA. Frequency of hepatic visualization during I-131 imaging for metastatic thyroid carcinoma. Clin Nucl Med. 1988;13(9):657-60.

29. Tatar FA, Morita E, Ituarte PH, Cavalieri RR, Duh QY, Price DC, et al. Association between residual thyroid carcinoma and diffuse hepatic uptake of 131I following radioiodine ablation in postoperative total thyroidectomy patients. World J Surg. 2001;25(6):718-22.

30. ••Pinho DFCA, Patel A, Peng F, Wachsmann JW. That's not metastatic thyroid cancer: patterns of non-malignant radioiodine uptake. Imaging J Clin Medical Sci. 2017;4:001-0005 A recent case series on false-positive radioiodine uptake focusing on underlying mechanisms.

31. Arce MB, Molina TC, Hernandez TM, de la Cinta CMM, Herrero $\mathrm{CH}$, De la Riva PPA, et al. Thymic uptake after highdose I-131 treatment in patients with differentiated thyroid carcinoma: a brief review of possible causes and management. Endocrinol Nutr. 2015;62(1):19-23.

32. Wilson LM, Barrington SF, Morrison ID, Kettle AG, O'Doherty MJ, Coakley AJ. Therapeutic implications of thymic uptake of radioiodine in thyroid carcinoma. Eur $J$ Nucl Med. 1998;25(6):622-8.

33. Davidson J, McDougall IR. How frequently is the thymus seen on whole-body iodine-131 diagnostic and post-treatment scans? Eur J Nucl Med. 2000;27(4):425-30.

34. Spitzweg C, Joba W, Eisenmenger W, Heufelder AE. Analysis of human sodium iodide symporter gene expression in extrathyroidal tissues and cloning of its complementary deoxyribonucleic acids from salivary gland, mammary gland, and gastric mucosa. $J$ Clin Endocrinol Metab. 1998;83(5):1746-51.

35. Kim MJ, Oh SW, Youn H, Na J, Kang KW, Park DJ, et al. Thyroid-related protein expression in the human thymus. Int $\mathrm{J}$ Endocrinol. 2017;2017:8159892.

36. Zimmermann MB, Andersson M. Assessment of iodine nutrition in populations: past, present, and future. Nutr Rev. 2012;70(10):553-70.

37. Mulazimoglu M, Koca S, Tamam MO, Uyanik E, Ozpacaci T. False-positive findings in post-treatment iodine-131 whole-body scintigraphy in a nasolacrimal sac cyst, confirmed with SPECT/ CT and MRI. Clin Nucl Med. 2011;36(9):805-7.
38. Song HC, Kim SM, Heo YJ, Bom HS. Retention of iodine-131 in a thoracic esophageal diverticulum mimicking metastatic thyroid cancer. Clin Nucl Med. 2002;27(12):896-7.

39. Boulahdour H, Meignan M, Melliere D, Braga F, Galle P. Falsepositive I-131 scan induced by Zenker's diverticulum. Clin Nucl Med. 1992;17(3):243-4.

40. Rashid K, Johns W, Chasse K, Walker M, Gupta SM. Esophageal diverticulum presenting as metastatic thyroid mass on iodine-131 scintigraphy. Clin Nucl Med. 2006;31(7):405-8.

41. Nguyen BD, Roarke MC. Epiphrenic diverticulum: potential pitfall in thyroid cancer iodine-131 scintigraphy. Clin Nucl Med. 2005;30(9):631-2.

42. Francese C, Schlumberger M, Travagli JP, Vera P, Caillou B, Parmentier C. Iodine 131 uptake in a pleuropericardial cyst: case report of a false-positive radioiodine total body scan result in a patient with a thyroid cancer. Eur J Nucl Med. 1991;18(9):779-80.

43. Lejeune M, Heron C, Tenenbaum F, Sarfati PO, Louvel A, Luton JP, et al. Iodine 131 uptake by a bronchogenic cyst in a patient with differentiated carcinoma of the thyroid gland. Presse Med. 2000;29(24):1345-7.

44. Agriantonis DJ, Hall L, Wilson MA. Pitfalls of I-131 whole body scan interpretation: bronchogenic cyst and mucinous cystadenoma. Clin Nucl Med. 2008;33(5):325-7.

45. Kayano D, Michigishi T, Ichiyanagi K, Inaki A, Kinuya S. I-131 uptake in a thymic cyst. Clin Nucl Med. 2010;35(6):438-9.

46. Singh AK, Bodolan AA, Gilbert MP. A false positive I-131 metastatic survey caused by radioactive iodine uptake by a benign thymic cyst. Case Rep Endocrinol. 2017;2017:6469015.

47. Serafini A, Sfakianakis G, Georgiou M, Morris J. Breast cyst simulating metastases on iodine-131 imaging in thyroid carcinoma. J Nucl Med. 1998;39(11):1910-2.

48. Caplan RH, Gundersen GA, Abellera RM, Kisken WA. Uptake of iodine-131 by a Meckel's diverticulum mimicking metastatic thyroid cancer. Clin Nucl Med. 1987;12(9):760-2.

49. Borkar S, Grewal R, Schoder H. I-131 uptake demonstrated in the appendix on a posttreatment scan in a patient with thyroid cancer. Clin Nucl Med. 2008;33(8):551-2.

50. Bakheet SM, Hammami MM, Powe J. False-positive radioiodine uptake in the abdomen and the pelvis: radioiodine retention in the kidneys and review of the literature. Clin Nucl Med. 1996;21(12):932-7.

51. Husmann L, Scheffel H, Stumpe K, Schmid S, Alkadhi H, Goerres GW. Pyelocaliceal diverticulum as a rare pitfall in I-131 post-therapy scanning. Clin Nucl Med. 2010;35(6):443-4.

52. Okuyama C, Ushijima Y, Kikkawa M, Yamagami T, Nakamura $\mathrm{T}$, Kobayashi K, et al. False-positive I-131 accumulation in a liver cyst in a patient with thyroid carcinoma. Clin Nucl Med. 2001;26(3):198-201.

53. Gunawardana DH, Pitman AG, Lichtenstein M. Benign hepatic cyst mimicking a functional thyroid carcinoma metastasis on whole-body I-131 imaging. Clin Nucl Med. 2003;28(6):527-8.

54. Omur O, Ozbek SS, Akgun A, Yazici B, Mutlukoca N, Ozcan Z. False-positive I-131 accumulation in a hepatic hydatid cyst. Clin Nucl Med. 2007;32(12):930-2.

55. Giuffrida D, Fornito MC, Pellegriti G, Regalbuto C, Vigneri G. False positive 131I total body scan due to bilateral polycystic renal disease. J Endocrinol Investig. 1997;20(6):342-4.

56. Wen C, Iuanow E, Oates E, Lee SL, Perrone R. Post-therapy iodine-131 localization in unsuspected large renal cyst: possible mechanisms. J Nucl Med. 1998;39(12):2158-61.

57. Letaief B, Boughattas S, Guezguez M, Hassine H, Essabbah H. Abdominal uptake of I-131 revealing a renal cyst. Clin Nucl Med. 2001;26(3):255-6. 
58. Kraft O, Sirucek P, Mrhac L, Havel M. I-131 false positive uptake in a huge parapelvic renal cyst. Nucl Med Rev Cent East Eur. 2011;14(1):36-7.

59. -Lee JY, Song HS, Choi JH, Lee JS. Iodine uptake in retroperitoneal cysts after radioactive iodine treatment. Indian $\mathbf{J}$ Nucl Med. 2020;35(1):76-7 New recent case report on retroperitoneal cysts RAI uptakeNew recent case report on retroperitoneal cysts RAI uptake.

60. Lungo M, Tenenbaum F, Chaumerliac P, Vons C, Mirat A, Beuzen F, et al. Ovarian endometriosis cyst with iodine 131 uptake: first case of false positive in the follow up for differentiated thyroid carcinoma. Ann Endocrinol (Paris). 2000;61(2):147-50.

61. Jang HY, Kim BH, Kim WJ, Jeon YK, Kim SS, Kim YK, et al. False-positive radioiodine uptake in a functional ovarian cyst in a patient treated with total thyroidectomy for papillary cancer. Intern Med. 2013;52(20):2321-3.

62. Liu S, Zhang M, Pan Y, Qu Q, Wu H, Lv J, et al. Nabothian cyst associated with high false-positive incidence of iodine-131 uptake in whole-body scans after treatment for differentiated thyroid cancer. Nucl Med Commun. 2013;34(12):1204-7.

63. Turoglu HT, Naddaf S, Young I, Abdel-Dayem HM. Infected sebaceous cyst. A cause for false-positive total-body I-123 metastatic survey for thyroid cancer. Clin Nucl Med. 1996;21(11):887.

64. Brucker-Davis F, Reynolds JC, Skarulis MC, Fraker DL, Alexander HR, Weintraub BD, et al. False-positive iodine-131 whole-body scans due to cholecystitis and sebaceous cyst. J Nucl Med. 1996;37(10):1690-3

65. Bural GG, Peel RL, Mountz JM. Benign epithelial cyst mimicking thyroid cancer metastasis: a false-positive finding on post-therapy I-131 scan. Clin Nucl Med. 2012;37(1):88-90.

66. Giuffrida D, Garofalo MR, Cacciaguerra G, Freni V, Ippolito A, Regalbuto C, et al. False positive 131I total body scan due to an ectasia of the common carotidis. J Endocrinol Investig. 1993;16(3):207-11

67. Mena Bares LM, Vallejo Casas JA, Moreno Ortega E, del Real NR, Maza Muret FR, Latre Romero JM. I-131 visualization of thoracic aortic aneurysm after radioiodine administration for thyroid carcinoma. Clin Nucl Med. 2008;33(8):553-4.

68. De Wilde R, Bordt J, Hesseling M, Vancaillie T. Ovarian cystostomy. Acta Obstet Gynecol Scand. 1989;68(4):363-4.

69. Yuoness S, Rachinsky I, Driedger AA, Belhocine TZ. Differentiated thyroid cancer with epiphora: detection of nasolacrimal duct obstruction on I-131 SPECT/CT. Clin Nucl Med. 2011;36(12):1149-52.

70. Wolff H, Breda DJ, Da Silva N, Hartmann AA. False-positive I-131 deposition in a parotid gland duct ectasia. Clin Nucl Med. 1998;23(4):257-9.

71. Mandel SJ, Mandel L. False-positive xerostomia following radioactive iodine treatment: case report. Oral Surg Oral Med Oral Pathol Oral Radiol Endod. 2007;103(2):e43-7.

72. Ozdemir A, Gungor F, Ozugur S, Cubuk M, Boz A, Karayalcin B. Abnormal iodine-131 uptake in the mediastinum caused by achalasia. Clin Nucl Med. 1998;23(10):706-7.

73. Schuster DM, Alazraki N. Esophageal scarring causing falsepositive uptake on I-131 whole-body imaging. Clin Nucl Med. 1998;23(5):334.

74. Freeman M, Roach P, Robinson B, Shields M. Hiatal hernia in iodine-131 scintigraphy: a potential cause of false-positive midline thoracic uptake. Clin Nucl Med. 2003;28(8):709-10.

75. Ceylan Gunay E, Erdogan A. Mediastinal radioiodine uptake due to hiatal hernia: a false-positive reason in 131I scan. Rev Esp Med Nucl. 2010;29(2):95.
76. Zucker RJ, Bradley YC, Toney MO, Bridwell RS. Gastric volvulus detected with iodine-131 whole-body imaging. Clin Nucl Med. 2000;25(4):303-5.

77. You DL, Tzen KY, Chen JF, Kao PF, Tsai MF. False-positive whole-body iodine-131 scan due to intrahepatic duct dilatation. J Nucl Med. 1997;38(12):1977-9.

78. Attard M, Marozzi P, Gambino L, Janni F, Salice P, Ficola U, et al. False-positive results of an iodine-131 whole-body scan caused by an ectopic kidney. Clin Nucl Med. 2001;26(3):271-3.

79. Mattern M, Staab E. I-131 localization in hematocolpos: a differential diagnosis consideration for pelvic I-131 uptake. Clin Nucl Med. 2007;32(8):659-60.

80. Burlison JS, Hartshorne MF, Voda AM, Cocks FH, Fair JR. SPECT/CT localization of oral radioiodine activity: a retrospective study and in-vitro assessment. Nucl Med Commun. 2013;34(12):1216-22.

81. Savas H, Wong KK, Saglik B, Hubers D, Ackermann RJ, Avram AM. SPECT/CT characterization of oral activity on radioiodine scintigraphy. J Clin Endocrinol Metab. 2013;98(11):4410-6.

82. Garger YB, Winfeld M, Friedman K, Blum M. In Thyroidectomized thyroid cancer patients, false-positive I-131 whole body scans are often caused by inflammation rather than thyroid cancer. J Investig Med High Impact Case Rep. 2016;4(1):2324709616633715.

83. Campenni A, Minutoli F, Pecorella GR, Baldari S. Unusual radioiodine uptake in a patient with thyroid cancer and cranial metallic clips. Nuklearmedizin. 2002;41(6):N89-90.

84. Modoni S, Martino G, Guerra M, Frusciante V. Unusual radioiodine uptake caused by metallic sutures in the skull in a patient with thyroid cancer. Clin Nucl Med. 2000;25(12):1053-4.

85. •Abbasain H, Emami F, Banezhad F, Sadeghi R. Multiple nonmalignant iodine uptake in a 131I whole body scan of a patient with papillary thyroid carcinoma: Importance of SPECT/CT. Iran J Nucl Med. 2020;28(1):39-42 Another example that demonstrates the importance of corresponding cross-sectional images with RAIN.

86. Camponovo EJ, Goyer PF, Silverman ED, Kistler AM, Yudt WM. Axillary iodine-131 accumulation due to perspiration. Clin Nucl Med. 1989;14(10):762-3.

87. Schlosser J, Paliou M, Bravo-Vera R, Sheikh A, Gouller A. False positive uptake in post-treatment iodine-131 whole-body scans secondary to contamination. Thyroid. 2007;17(1):81-2.

88. • Lee JY, Song HS, Kang M. Physiological uptake of radioactive iodine around an artificial eyeball observed with single-photon emission computed tomography/computed tomography after radioactive iodine treatment. Nucl Med Mol Imaging. 2020;54(4):204-6 New recent case reports on artificial eyeball tear contamination causing false-positive RAI uptake.

89. ${ }^{-K i m}$ IH, Yoon JK, Lee SJ, Jeong E, An YS. A case of radioactive iodine uptake found in artificial eye. Clin Nucl Med. 2019;44(4):317-8 New recent case reports on artificial eyeball tear contamination causing false-positive RAI uptake.

90. Ain KB, Shih WJ. False-positive I-131 uptake at a tracheostomy site. Discernment with Tl-201 imaging. Clin Nucl Med. 1994;19(7):619-21.

91. Van den Broek PJ, Buys LF, Van Furth R. Interaction of povidone-iodine compounds, phagocytic cells, and microorganisms. Antimicrob Agents Chemother. 1982;22(4):593-7.

92. Jong I, Taubman K, Schlicht S. Bronchiectasis simulating pulmonary metastases on iodine-131 scintigraphy in well-differentiated thyroid carcinoma. Clin Nucl Med. 2005;30(10):688-9.

93. Song HC, Heo YJ, Kim SM, Bom HS. Iodine-131 uptake in focal bronchiectasis mimicking metastatic thyroid cancer. Clin Nucl Med. 2003;28(4):351-2. 
94. Demidowich AP, Kundu A, Reynolds JC, Celi FS. False-positive radioactive iodine uptake mimicking miliary lung metastases in a patient affected by papillary thyroid cancer and $\operatorname{IgA}$ deficiency. Nucl Med Mol Imaging. 2016;50(3):270-2.

95. Bakheet SM, Hammami MM, Powe J. Radioiodine bronchogram in acute respiratory tract infection. Clin Nucl Med. 1997;22(5):308-9.

96. • Chausse G, Kader T, Abikhzer G, Probst S. Asthmatic exacerbation as a cause of false-positive whole-body iodine scan in a patient with treated papillary thyroid carcinoma. Clin Nucl Med. 2018;43(4):256-7 New recent case report on asthma exacerbation as a cause of false-positive RAI.

97. Ahn BC, Lee SW, Lee J, Kim C. Pulmonary aspergilloma mimicking metastasis from papillary thyroid cancer. Thyroid. 2011;21(5):555-8.

98. Picolos MK, Habra M, Safdar A, Sarlis NJ. Inactive pulmonary tuberculosis mimicking metastasis from papillary thyroid carcinoma in diagnostic radioiodine whole-body scintigraphy. Thyroid. 2005;15(9):1105-6.

99. Bakheet SM, Hammami MM, Powe J, Bazarbashi M, Al SH. Radioiodine uptake in inactive pulmonary tuberculosis. Eur $\mathbf{J}$ Nucl Med. 1999;26(6):659-62.

100. Otsuka N, Fukunaga M, Morita K, Ono S, Nagai K, Katagiri M, et al. Iodine-131 uptake in a patient with thyroid cancer and rheumatoid arthritis during acupuncture treatment. Clin Nucl Med. 1990;15(1):29-31.

101. •Kumar RK, Krishnamurthy A, Rangarajan GK, Anandi N, Parvathnathan N. False positive helmet sign on radioactive iodine-131 scintigraphy. Indian J Cancer. 2019;56(4):379-80 Another recent case report on folliculitis and perspiration as a cause of RAI contamination.

102. Kinuya S, Yokoyama K, Michigishi T, Tonami N. I-131 accumulation in folliculitis of the scalp. Clin Nucl Med. 1996;21(10):807-8.

103. Kolla IS, Alazraki NP, Watts NB. Sialadenitis mimicking metastatic thyroid carcinoma. Clin Nucl Med. 1989;14(8):564-6.

104. Bakheet SM, Hammami MM, Powe J, Larsson S. Radioiodine uptake in the head and neck. Endocr Pract. 2000;6(1):37-41.

105. Pena-Pardo FJ, de la Jara CA, Morejon FJ, Gonzalez SM, Vila FJ, Brugarolas-Masllorens A. Solitary focus in the liver in a thyroid cancer patient after a whole body scan with 131 iodine. Rev Esp Med Nucl. 2007;26(5):294-6.

106. Andreu J, Mauleon S, Pallisa E, Majo J, Martinez-Rodriguez M, Caceres J. Miliary lung disease revisited. Curr Probl Diagn Radiol. 2002;31(5):189-97.

107. Naddaf SY, Akisik MF, Omar WS, Young I, Abdel-Dayem HM. I-123 uptake in the chest wall after needle biopsy of a pulmonary nodule. A cause for false-positive I-123 uptake. Clin Nucl Med. 1997;22(8):572-3.

108. Regalbuto C, Buscema M, Arena S, Vigneri R, Squatrito S, Pezzino V. False-positive findings on (131)I whole-body scans because of posttraumatic superficial scabs. J Nucl Med. 2002;43(2):207-9.

109. Ilgan S, Narin Y, Arslan N, Aksu A, Bayhan H. Warthin's tumor and I-131 body scan. Clin Nucl Med. 1999;24(9):721-2.

110. Caglar M, Tuncel M, Usubutun A. Increased uptake on I-131 whole-body scintigraphy in Warthin tumor despite false-negative Tc-99m pertechnetate salivary gland scintigraphy. Clin Nucl Med. 2003;28(11):945-6.

111. Gekeler J, Luers JC, Krohn T, Beutner D. False positive findings in F-18 FDG PET and whole body scans with I-131 in Warthin tumor of the parotid gland. Clin Nucl Med. 2010;35(2):105-6.
112. Broekhuizen-de Gast H, van Isselt H, Roef M, Lam M. Oncocytoma of the parotid gland causing false-positive result on I-131 whole-body scintigraphy. Clin Nucl Med. 2011;36(8):701-3.

113. Berger F, Unterholzner S, Diebold J, Knesewitsch P, Hahn K, Spitzweg C. Mammary radioiodine accumulation due to functional sodium iodide symporter expression in a benign fibroadenoma. Biochem Biophys Res Commun. 2006;349(4):1258-63.

114. Kim EE, Pjura G, Gobuty A, Verani R. 131I uptake in a benign serous cystadenoma of the ovary. Eur J Nucl Med. 1984;9(9):433-5.

115. Qiu ZL, Xu YH, Song HJ, Luo QY. Unusual (1)(3)(1)I uptake in a benign mucinous cystadenoma of the ovary in a patient with papillary thyroid cancer. Clin Nucl Med. 2010;35(12):965-6.

116. Flug J, Lameka K, Lee R, Katz DS, Sung WW, Yung E. Falsepositive I-131 uptake by an ovarian serous cystadenofibroma. Clin Nucl Med. 2012;37(2):178-80.

117. Almohamad FA, Ahmad T, Ahmad B, Hussain K, Hadid L, Zein $\mathrm{M}$, et al. False-positive radioiodine accumulation in a huge pelvic mass after thyroidectomy for papillary carcinoma, a case report from Syria. J Surg Case Rep. 2018;2018(2):rjy028.

118. Schmidt M, Scheidhauer K, Urbannek V, Luyken C, Friese M, Voth E, et al. Metastasizing follicular thyroid carcinoma with intracranial iodine 131 uptake in brain edema due to a frontal meningioma. Nuklearmedizin. 2000;39(1):38-9.

119. Sinha P, Conrad GR, Holzhauer M. Incidental detection of a falx meningioma on post-therapy radioiodide whole-body imaging. Clin Nucl Med. 2002;27(12):916-7.

120. Bulzico D, Vaisman F, Cordeiro de Pessoa NCH, Corbo R. Cavernous angioma mimicking a differentiated thyroid carcinoma brain metastasis. Clin Nucl Med. 2011;36(1):62-3.

121. Mohan V, Jones RC, Drake AJ 3rd, Daly PL, Shakir KM. Littoral cell angioma presenting as metastatic thyroid carcinoma to the spleen. Thyroid. 2005;15(2):170-5.

122. Karyagar S, Uyanik E, Mulazimoglu M, Karyagar SS. Uptake of (131)I on a post thyroid ablation whole body scan, due to cavernous liver hemangioma, mimicking metastases. Hell J Nucl Med. 2009;12(2):177-8.

123. Laguna R, Silva F, Vazquez-Selles J, Orduna E, Flores C. Vertebral hemangioma mimicking a metastatic bone lesion in well-differentiated thyroid carcinoma. Clin Nucl Med. 2000;25(8):611-3.

124. Khan S, Dunn J, Strickland N, Al-Nahhas A. Iodine-123 uptake in vertebral haemangiomas in a patient with papillary thyroid carcinoma. Nucl Med Rev Cent East Eur. 2008;11(1):30-3.

125. Wapnir IL, van de Rijn M, Nowels K, Amenta PS, Walton K, Montgomery $\mathrm{K}$, et al. Immunohistochemical profile of the sodium/iodide symporter in thyroid, breast, and other carcinomas using high density tissue microarrays and conventional sections. J Clin Endocrinol Metab. 2003;88(4):1880-8.

126. Wapnir IL, Goris M, Yudd A, Dohan O, Adelman D, Nowels K, et al. The Na+/I- symporter mediates iodide uptake in breast cancer metastases and can be selectively down-regulated in the thyroid. Clin Cancer Res. 2004;10(13):4294-302.

127. Poole VL, McCabe CJ. Iodide transport and breast cancer. J Endocrinol. 2015;227(1):R1-12.

Publisher's Note Springer Nature remains neutral with regard to jurisdictional claims in published maps and institutional affiliations. 